\title{
In vitro antioxidant and anticancer effects of solvent fractions from prunella vulgaris var. lilacina
}

\author{
Yu-Jin Hwang ${ }^{1,2}$, Eun-Ju Lee ${ }^{1}$, Haeng-Ran Kim and Kyung-A Hwang ${ }^{1 *}$
}

\begin{abstract}
Background: Recently, considerable attention has been focused on exploring the potential antioxidant properties of plant extracts or isolated products of plant origin. Prunella vulgaris var. lilacina is widely distributed in Korea, Japan, China, and Europe, and it continues to be used to treat inflammation, eye pain, headache, and dizziness. However, reports on the antioxidant activities of $P$. vulgaris var. lilacina are limited, particularly concerning the relationship between its phenolic content and antioxidant capacity. In this study, we investigated the antioxidant and anticancer activities of an ethanol extract from P. vulgaris var. lilacina and its fractions.
\end{abstract}

Methods: Dried powder of $P$. vulgaris var. lilacina was extracted with ethanol, and the extract was fractionated to produce the hexane fraction, butanol fraction, chloroform fraction and residual water fraction. The phenolic content was assayed using the Folin-Ciocalteu colorimetric method. Subsequently, the antioxidant activities of the ethanol extract and its fractions were analyzed employing various antioxidant assay methods including DPPH, FRAP, ABTS, SOD activity and production of reactive oxygen species. Additionally, the extract and fractions were assayed for their ability to exert cytotoxic activities on various cancer cells using the MTT assay. We also investigated the expression of genes associated with apoptotic cell death by RT-PCR.

Results: The total phenolic contents of the ethanol extract and water fraction of P. vulgaris var. lilacina were 303.66 and $322.80 \mathrm{mg} \mathrm{GAE} / \mathrm{g}$ dry weight (or fractions), respectively. The results showed that the ethanol extract and the water fraction of $P$. vulgaris var. lilacina had higher antioxidant content than other solvent fractions, similar to their total phenolic content. Anticancer activity was also tested using the HepG2, HT29, A549, MKN45 and HeLa cancer cell lines. The results clearly demonstrated that the $P$. vulgaris var. lilacina ethanol extract induced significant cytotoxic effects on the various cancer cell lines, and these effects were stronger than those induced by the $P$. vulgaris var. lilacina solvent fractions. We also investigated the expression of genes associated with apoptotic cell death. We confirmed that the P. vulgaris var. lilacina ethanol extract and water fraction significantly increased the expression of p53, Bax and Fas.

Conclusions: These results suggest that the ethanol extract from $P$. vulgaris var. lilacina and its fractions could be applied as natural sources of antioxidants and anticancer activities in food and in the pharmaceutical industry.

Keywords: Prunella vulgaris var. lilacina, Antioxidative activity, Anticancer activity

\section{Background}

Oxidative stress is caused by reactive oxygen species (ROS), which are associated with many pathological disorders such as atherosclerosis, diabetes, ageing and cancer [1-3]. In order to protect human beings against oxidative damage, synthetic antioxidants such as BHA and BHT were created due to demand [4]. However, there has been concern regarding the toxicity and carcinogenic effects of synthetic

\footnotetext{
* Correspondence: kah366@korea.kr

'Department of Agrofood Resources, National Academy of Agricultural

Science, RDA, Suwon, Gyeonggi-do 441-853, Republic of Korea

Full list of author information is available at the end of the article
}

antioxidants $[5,6]$. Thus, it is important to identify new sources of safe and inexpensive antioxidants of natural origin. Natural antioxidants, especially plant phenolics, flavonoids, tannins and anthocyanidins, are safe and are also bioactive [7]. Therefore, in recent years, considerable attention has been focused on exploring the potential antioxidant properties of plant extracts or isolated products of plant origin [8].

Prunella vulgaris var. lilacina is widely distributed in Korea, Japan, China, and Europe, and it continues to be used to treat inflammation, eye pain, headache, and

\section{Biomed Central}

(c) 2013 Hwang et al.; licensee BioMed Central Ltd. This is an open access article distributed under the terms of the Creative Commons Attribution License (http://creativecommons.org/licenses/by/2.0), which permits unrestricted use, distribution, and reproduction in any medium, provided the original work is properly cited. 
dizziness $[9,10]$. It is rich in active compounds known to significantly affect human health, such as triterpenoid, rosmarinic acid, hyperoside, ursolic acid, and flavonoids [11-16]. Furthermore, P. vulgaris var. lilacina has been shown to have anti-allergic, anti-inflammatory, anti-oxidative, anti-microbial, and anti-viral effects [17-19]. However, reports on the antioxidant activities of $P$. vulgaris var. lilacina are limited, particularly concerning the relationship between its phenolic content and antioxidant capacity. Therefore, the aims of this study were to identify new sources of antioxidants from $P$. vulgaris var. lilacina extract. Additionally, the effects of the extraction solvent (70\% ethanol, hexane, butanol, chloroform, or water) on the total phenolic content and antioxidant activities of $P$. vulgaris var. lilacina were investigated.

\section{Methods}

\section{Reagents}

The reagents 1,1-diphenyl-1-picrylhydrazyl (DPPH), 2,2' azinibis 3-ethyl benzothiazoline-6-sulfonic acid (ABTS), $\alpha$-tocopherol, 2,4,6-tris(2-pyridyl)-s-triazine (TPTZ), iron (III) chloride hexahydrate, gallic acid, Folin and Ciocalteu's phenol reagent, 3-(4,5-dimethylthiazol-2-yl)-2,5-diphenyltetrazolium bromide (MTT) and lipopolysaccharides (LPS) were purchased from Sigma-Aldrich (St. Louis, MO, USA). Iron(II) sulfate heptahydrate and acetic acid were purchased from Junsei (Tokyo, Japan). A superoxide dismutase-WST kit was purchased from Dojindo (Kumamoto, Japan). Dulbecco's Modified Eagle's Medium (DMEM), RPMI 1640 medium, fetal bovine serum (FBS), and penicillin-streptomycin were obtained from Invitrogen (Carlsbad, CA, USA).

\section{Sample preparation and extraction}

Whole plants of $P$. vulgaris var. lilacina were purchased from the Plant Extract Bank (\#007-017, Dae-Jeon, Korea). Dried $P$. vulgaris var. lilacina was milled into powder of 80 -mesh particle size and stored at $-70^{\circ} \mathrm{C}$. The dried $P$. vulgaris var. lilacina was extracted three times with $70 \%$ ethanol. The $70 \%$ ethanol extract powder (10 g) was suspended in $500 \mathrm{~mL}$ of distilled water and extracted with $500 \mathrm{~mL}$ of the following solvents in a stepwise manner: hexane, chloroform, and butanol. Each fraction was filtered through Whatman filter paper No. 2 (Advantec, Tokyo, Japan). Subsequently, the filtrates were combined and evaporated under a vacuum and then lyophilized with a freeze dryer (Ilshine Lab, Suwon, Korea) at $-70^{\circ} \mathrm{C}$ under reduced pressure $(<20 \mathrm{~Pa})$. The dry residue was stored at $-20^{\circ} \mathrm{C}$. For further analysis, we reconstituted the dry extract and fractions with DMSO.

\section{Total phenolic content}

The total phenolic contents of P. vulgaris var. lilacina extract and its fractions were determined using the FolinCiocalteu method [20]. The extract and each fraction were oxidized with Folin-Ciocalteu's reagents, and then, the reaction was neutralized with $10 \%$ sodium carbonate. After incubation at room temperature for $1 \mathrm{~h}$, the absorbance of the reaction mixture was measured at $725 \mathrm{~nm}$ using a microplate reader (Molecular Devices, Sunnyvale, CA, USA). Quantification was performed based on a standard curve with gallic acid. Results were expressed as milligrams gallic acid equivalent (GAE) per gram of dry weight of extract (or fractions).

\section{DPPH radical scavenging activity}

Analysis of DPPH radical-scavenging activity was carried out according to the Blois method [21]. 0.3 mM DPPH was added to each sample. After incubation for $30 \mathrm{~min}$ in the dark at room temperature, the absorbance was measured at $518 \mathrm{~nm}$ using a microplate reader. $\alpha$-Tocopherol was used as a positive control. Percent reduction of the DPPH radical was calculated in the following way: inhibition concentration $(\%)=100-\left(\mathrm{A}_{\text {sample }} / \mathrm{A}_{\text {control }}\right) \times 100$,

where $A_{\text {control }}$ is the absorbance of the control reaction (containing all reagents except the test sample), and $\mathrm{A}_{\text {sample }}$ is the absorbance of the test sample. Tests were carried out in triplicate. For the final results, $\mathrm{RC}_{50}$ values (the concentrations required for 50\% reduction of $\mathrm{DPPH}$ by $30 \mathrm{~min}$ after starting the reaction) were calculated from the absorbance diminished by $50 \%$. The experiment was performed in triplicate.

\section{Ferric-reducing antioxidant power (FRAP) activity}

FRAP activity was determined using manual assay methods [22]. The working fluid was freshly prepared by mixing acetate buffer (300 mM, pH 3.6) with TPTZ in $\mathrm{HCl}$ and iron (III) chloride hexahydrate. Each sample solution or $\alpha$-tocopherol was added to $3 \mathrm{~mL}$ of working fluid, and the mixture was left for $4 \mathrm{~min}$ at room temperature. The absorbance was measured at $593 \mathrm{~nm}$. The results were expressed as iron (II) sulfate heptahydrate $\left(\mathrm{FeSO}_{4}\right)$ equivalents.

\begin{tabular}{lc}
$\begin{array}{l}\text { Table } 1 \text { Total phenolic contents of various solvent } \\
\text { fractions obtained from the ethanol extract of Prunella } \\
\text { vulgaris var. lilacina }\end{array}$ \\
\hline Solvent & Total polyphenoles $^{\mathbf{1})}(\mathbf{m g ~ G A E} / \mathbf{g})$ \\
\hline $70 \%$ ethanol & $303.66 \pm 3.61^{\mathrm{a}}$ \\
Hexane & $109.31 \pm 4.08^{\mathrm{c}}$ \\
Butanol & $242.03 \pm 6.16^{\mathrm{b}}$ \\
Chloroform & $124.45 \pm 0.24^{\mathrm{c}}$ \\
Water & $322.80 \pm 15.12^{\mathrm{a}}$ \\
\hline
\end{tabular}

${ }^{1)}$ Total phenolic content expressed in mg of gallic acid equivalent (GAE) per gram of dry weight of extract (or fractions).

Values are mean $\pm S E M$. Values with different superscripts within same column are significantly different $(\mathrm{p}<0.05)$. 


\section{$A B T S$ radical cation scavenging activity}

The ABTS assay was based on the ability of different fractions to scavenge the ABTS radical cation in comparison to a standard ( $\alpha$-tocopherol) [23]. The radical cation was prepared by mixing $7 \mathrm{mM}$ ABTS with $2.45 \mathrm{mM}$ potassium persulfate $(1: 1 \mathrm{v} / \mathrm{v})$ and leaving the mixture for $24 \mathrm{~h}$ until the reaction was completed and the absorbance was stable. The ABTS radical solution was diluted with PBS to an absorbance of $0.7 \pm 0.02$ at $732 \mathrm{~nm}$. The photometric assay was conducted with $180 \mu \mathrm{L}$ of ABTS radical solution and $20 \mu \mathrm{L}$ of samples; measurements were taken at $732 \mathrm{~nm}$ after $1 \mathrm{~min}$. The antioxidative activity of the tested samples was calculated by determining the decrease in absorbance. The free radical scavenging capacity was expressed by $\mathrm{RC}_{50}$.

\section{Superoxide dismutase (SOD) activity}

Superoxide dismutase activity was determined using the highly water-soluble tetrazolium salt WST-1, which produces a water-soluble formazan dye upon reduction with a superoxide anion. SOD activity was determined using an SOD assay kit (Dojindo, Kumamoto, Japan) in accordance with the manufacturer's instructions. Briefly, WST working solution was made by diluting $1 \mathrm{~mL}$ of WST solution into $19 \mathrm{ml}$ of buffer solution. Enzyme working solution was made after the enzyme solution tube was centrifuged for 5 sec. Fifteen microliters of enzyme solution were diluted with $2.5 \mathrm{~mL}$ of dilution buffer. SOD activity was expressed as the percentage of inhibition rate.

\section{Cells and culture}

The mouse macrophage cell line RAW264.7, human liver cancer cell line HepG2, human colon cancer cell line HT29, human lung cancer cell line A549, human stomach cancer cell line MKN-45 and human cervical cancer cell line HeLa were purchased from the Korean Cell Line Bank (Seoul, Korea). The cell lines were grown in RPMI 1640 medium or DMEM with 10\% FBS and 1\% penicillinstreptomycin and incubated at $37^{\circ} \mathrm{C}$ in $5 \% \mathrm{CO}_{2}$.
Table 3 Correlation coefficients between the antioxidant capacity and phenolic content of various solvent fractions of the ethanol extract of Prunella vulgaris var. lilacina

\begin{tabular}{cccccc}
\hline Factor $^{1)}$ & TPC & DPPH & FRAP & ABTS & SOD \\
\hline TPC & 1.000 & -0.834 & $0.982^{* *}$ & -0.673 & 0.764 \\
DPPH & & 1.000 & -0.886 & $0.962^{* *}$ & $-0.993^{* *}$ \\
FRAP & & & 1.000 & -0.759 & 0.828 \\
ABTS & & & & 1.000 & $-0.980^{* *}$ \\
SOD & & & & & 1.000 \\
\hline 1)TPC: tola
\end{tabular}

${ }^{1)} T P C$ : total phenolic content, DPPH: DPPH radical scavenging activity, FRAP: ferric reducing antioxidant powers, $A B T S$ : $A B T S$ radical scavenging activity, $S O D$ : Superoxide dismutase activity. ${ }^{*} p<0.05,{ }^{* *} p<0.01$.

\section{Cell cytotoxicity assay}

Exponentially growing cells were collected and plated at $5 \times 10^{3}-1 \times 10^{4}$ cells/well. $P$. vulgaris var. lilacina ethanol extract and its solvent fractions in DMSO were diluted in PBS to obtain final concentrations of 10,50 and $100 \mu \mathrm{g} / \mathrm{mL}$. Cells were treated with samples for $24 \mathrm{~h}$, and MTT solution was added. After $4 \mathrm{~h}$, the media was removed, and DMSO was added to each well. The resulting absorbance was measured at $540 \mathrm{~nm}$ [24].

\section{Intracellular reactive oxygen species (ROS) scavenging activity}

For microscopic detection of ROS formation, RAW264.7 cells were grown to $80 \%$ confluence in six-well plates and treated with samples for $24 \mathrm{~h}$. After incubation, cells were incubated with dichlorofluorescein diacetate (DCF-DA) $(25 \mu \mathrm{M})$ for $30 \mathrm{~min}$ at $37^{\circ} \mathrm{C}$ in the dark. After several washings with PBS, cells were observed with a fluorescence microscope (Carl ZEISS, Oberkochen, Germany).

Real-time reverse transcription polymerase chain reaction analysis (RT-PCR)

To determine the expression levels of p53, Bax, Bcl-2 and Fas, RT-PCR was performed using a Qiagen Rotor-Gene Q real-time thermal cycler (Valencia, CA, USA) in accordance with the manufacturer's instructions. The cells were treated with $P$. vulgaris var. lilacina extracts and cultured for $24 \mathrm{~h}$.

Table 2 Total antioxidant capacities of various solvent fractions of the ethanol extract of Prunella vulgaris var. lilacina

\begin{tabular}{|c|c|c|c|c|}
\hline Solvent & DPPH $\mathrm{RH}_{50}{ }^{1)}{ }_{(\mathrm{ug} / \mathrm{ml})}$ & FRAP value $\left._{(m ~}^{2)} \mathrm{M} / \mathrm{g}\right)$ & ABTS $\mathrm{RC}_{50}{ }^{3)}(\mathrm{ug} / \mathrm{ml})$ & SOD activity $_{(\%)}^{4)}$ \\
\hline $70 \%$ ethanol & $73.05 \pm 10.3^{c}$ & $1.07 \pm 0.08^{\mathrm{ab}}$ & $60.08 \pm 3.19$ & $87.74 \pm 3.42$ \\
\hline Hexane & $1402.96 \pm 194^{a}$ & $0.48 \pm 0.09^{c}$ & $1469.12 \pm 10.1^{a}$ & $23.80 \pm 0.53$ \\
\hline Butanol & $83.52 \pm 7.01^{c}$ & $0.95 \pm 0.09^{b c}$ & $61.13 \pm 4.23^{c}$ & $92.54 \pm 0.32$ \\
\hline Chloroform & $521.58 \pm 8.10^{b}$ & $0.65 \pm 0.02^{b c}$ & $153.04 \pm 0.58^{b}$ & $72.75 \pm 3.91$ \\
\hline Water & $64.26 \pm 2.22^{c}$ & $1.24 \pm 0.12^{\mathrm{a}}$ & $53.78 \pm 2.60^{c}$ & $87.51 \pm 3.20$ \\
\hline a-tocoperol & $12.82 \pm 1.33$ & $15.0 \pm 26$ & $7.54 \pm 0.13$ & $99.64 \pm 2.45$ \\
\hline
\end{tabular}

${ }^{1)}$ Concentration of test sample required to produce $50 \%$ inhibition of the $D P P H$ radical.

${ }^{2)}$ Expressed as mmol of $\mathrm{Fe}^{2+}$ equivalents per gram of dry plant weight.

${ }^{3)}$ Concentration of test sample required to produce $50 \%$ inhibition of $A B T S$ radical.

4) Expressed as the superoxide inhibition rate of Prunella vulgaris var. lilacina ethanol extract and its fractions.

Values are mean $\pm S E M$. Values with different superscripts within same column are significantly different $(p<0.05)$. 

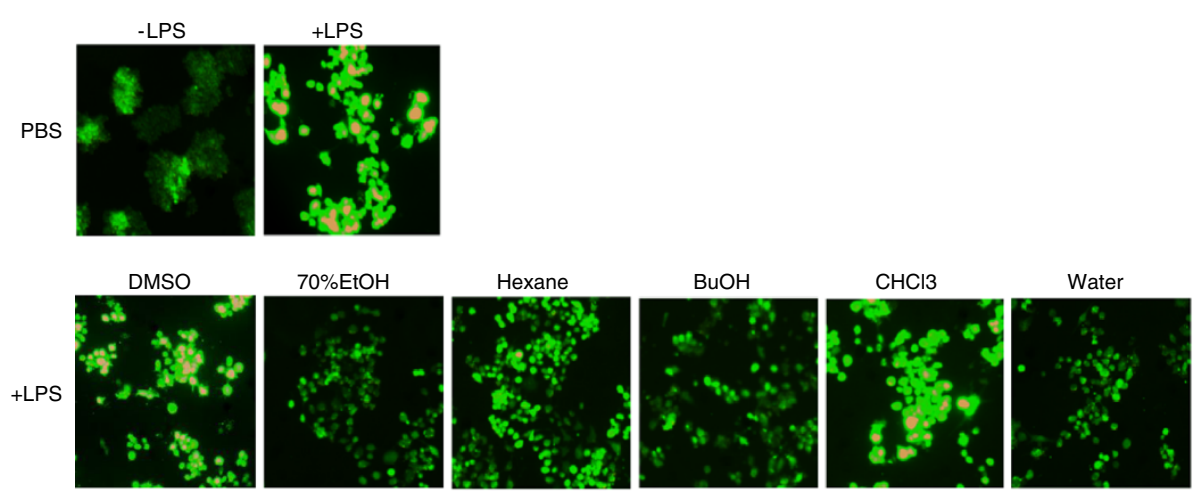

Figure 1 Reactive oxygen species scavenging activities of Prunella vulgaris var. lilacina. Cells were treated with solvent fractions of Prunella vulgaris var. lilacina at $10 \mu \mathrm{g} / \mathrm{mL}$. After treatment for $24 \mathrm{~h}$, ROS was stained with a DCF-DA for $30 \mathrm{~min}$, and the generation of ROS was analyzed with fluorescence microscopy.

Thereafter, cDNA was synthesized from the total RNA isolated from cells. The PCR reaction was performed using $2 \times$ SYBR Green mix (Qiagen, Valencia, CA, USA). All results were normalized to glyceraldehyde 3-phosphate dehydrogenase (GAPDH) expression. The following primer sequences were used for the real-time RT-PCR: GAPDH, 5'-CGG AGT CAA CGG ATT TGG TCG TAT-3' (forward), 5' -AGC CTT CTC CAT GGT GGT GAA GAC-3' (reverse); p53, 5'-GCT CTG ACT GTA CCA CCA TCC-3' (forward), 5'-CTC TCG GAA CAT CTC GAA GCG-3' (reverse); Bax, 5'-ATG GAC GGG TCC GGG GAG-3' (forward), 5' -TCA GCC CAT CTT CTT CCA-3' (reverse); Bcl-2, 5'-CAG CTG CAC CTG ACG-3' (forward), 5' -ATG CAC CTA CCC AGC-3' (reverse); Fas, 5' - TCT AAC TTG GGG TGG CTT TGT CTT C -3' (forward), 5' - GTG TCA TAC GCT TTC TTT CCA T-3' (reverse).

\section{Gas chromatography-mass spectrum analysis (GC-MS)}

GC-MS analysis was carried out using an Agilent 6890 gas chromatograph equipped with a DB-5 ms capillary column $(60 \mathrm{~m} \times 0.25 \mathrm{~mm}$; coating thickness $1.4 \mu \mathrm{m})$ and an Agilent 5975 MSD detector (Loveland, CO, USA). Analytical conditions were as follows: injector and transfer line temperatures of $250^{\circ} \mathrm{C}$; oven temperature was programmed from $50^{\circ} \mathrm{C}$ to $150^{\circ} \mathrm{C}$ at $10^{\circ} \mathrm{C} / \mathrm{min}$, from $150^{\circ} \mathrm{C}$ to $200^{\circ} \mathrm{C}$ at $7^{\circ} \mathrm{C} / \mathrm{min}$, and from $200^{\circ} \mathrm{C}$ to $250^{\circ} \mathrm{C}$ at $5^{\circ} \mathrm{C} / \mathrm{min}$; carrier gas helium at $1 \mathrm{~mL} / \mathrm{min}$; and split ratio 1:10. Identification of the constituents was based on comparison of the retention times with those of authentic samples.

\section{Statistical analysis}

Statistical analysis was performed with SPSS (version 17.0; SPSS Inc., Chicago, IL, USA). Descriptive statistics were used to calculate the mean and standard error of the mean (SEM). One-way analysis of variance was performed, and when the significance $(\mathrm{p}<0.05)$ was determined, the differences of the mean values were identified using Duncan's multiple range tests.

\section{Results and discussion \\ Extraction yield}

The yield of the extract and each fraction obtained from dry plant material was measured (Additional file 1: Table S1). The highest solid residue yields were obtained using butanol as the extraction solvent.

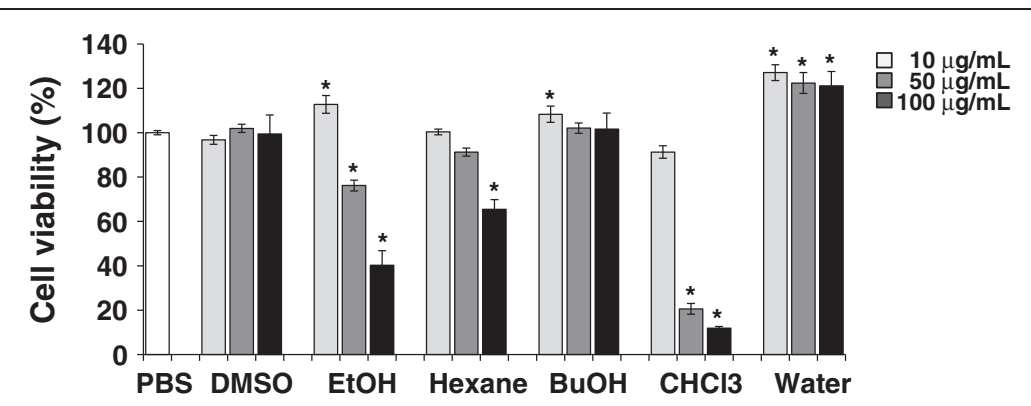

Figure 2 Effects of Prunella vulgaris var. lilacina on RAW264.7 cells as determined by the MTT assay. Cells were treated with solvent fractions of Prunella vulgaris var. lilacina at different concentrations $(10,50$ and $100 \mu \mathrm{g} / \mathrm{mL}$ ). After treatment for $24 \mathrm{~h}$, cell viability was measured with the MTT assay. Values are the mean \pm SEM; different marks within treatments indicate significant differences at ${ }^{*} p<0.05$ compared to the PBS group. 


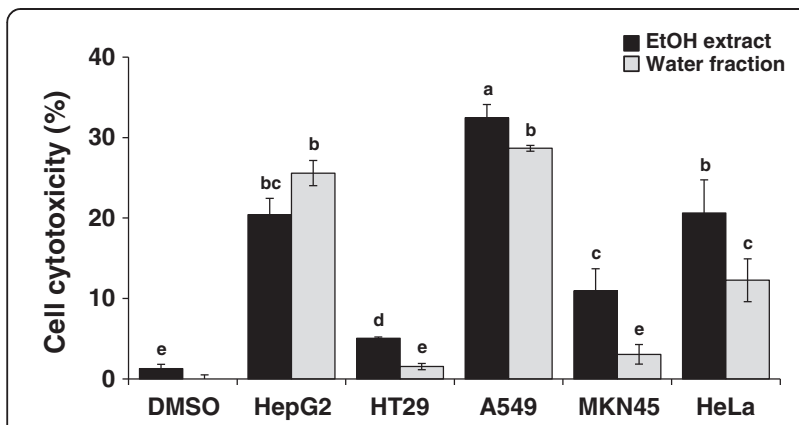

Figure 3 The cell cytotoxicity of the ethanol extract and water fraction from Prunella vulgaris var. lilacina against various cancer cell lines. Cells were treated with the ethanol extract and water fraction of $P$. vulgaris var. lilacina at $10 \mu \mathrm{g} / \mathrm{ml}$. After treatment for $24 \mathrm{~h}$, cell viability was measured with the MTT assay. Values are the means of three determinations \pm SEM. The different letters indicate a significant difference of $p<0.05$.

\section{Total phenolic content}

The total phenolic content of the P. vulgaris var. lilacina extract and its fractions were determined through a linear gallic acid standard curve and expressed as mg GAE/g dry weight of extract (or fractions). As shown Table 1, the total phenolic content of all fractions from $P$. vulgaris var. lilacina varied from 109.31 to $322.80 \mathrm{mg}$ GAE/g. The highest total phenolic content was detected in the water fraction $(322.80 \pm 15.12 \mathrm{mg} \mathrm{GAE} / \mathrm{g})$, whereas the lowest content was found in the hexane fraction $(109.31 \pm 4.08$ mg GAE/g). Phenolic compounds are reported to be associated with antioxidant activity, anticancer effects, and other biological functions and may prevent the development of aging and disease [25]. These results suggest that $P$. vulgaris var. lilacina extracts might have high antioxidant and anticancer activities.
Antioxidant capacities of prunella vulgaris var. Lilacina

Results of the radical scavenging capacities determined by DPPH, FRAP, ABTS and SOD assays are shown in Table 2. In the DPPH assay, the DPPH radical scavenging activity of all fractions from $P$. vulgaris var. lilacina extract increased as shown in Table 2; the $\mathrm{RC}_{50}$ values of radical scavenging activity for $\mathrm{DPPH}$ were found to be $73.05 \pm 10.32,1402.96 \pm 194.46,83.52 \pm 7.01,521.58 \pm 8.10$, $64.26 \pm 2.22$, and $12.82 \pm 1.33 \mu \mathrm{g} / \mathrm{mL}$ for ethanol extract, hexane, butanol, chloroform, water fractions and $\alpha$-tocopherol, respectively. The water fraction showed the highest $\mathrm{DPPH}$ radical-scavenging activity. The DPPH scavenging activity of all fractions showed a similar trend to the content of total phenolic compounds. The FRAP assay measures total antioxidant activity based on the reduction of the ferric tripyridyltriazine $\left(\mathrm{Fe}^{3+}-\mathrm{TPTZ}\right)$ complex to the ferrous form. The ferric complex reducing abilities of different fractions were similar to the results obtained for the radical scavenging assay; water fraction exhibited very strong ferric ion reducing activity, and the five fractions in descending order of strength of ferric ion reducing activity were water fraction $>$ ethanol extract $>$ butanol $>$ chloroform $>$ hexane fraction. In terms of the ABTS assay, the water fraction demonstrated the highest scavenging activity, followed by the ethanol extract, butanol fraction, chloroform fraction and hexane fraction, and these trends was similar to those of the DPPH and FRAP assays. For the results of the SOD activity assay, most fractions with the exception of hexane exhibited very high SOD activity similar to $\alpha$-tocopherol $(99.64 \pm 2.45 \%)$. However, there was no significant different among the fractions.

DPPH, FRAP, ABTS and SOD assays are widely used to determine the antioxidant capacity of plant extracts due to their simplicity, stability, and reproducibility [26]. In this study, the DPPH, FRAP, ABTS and SOD assays provided

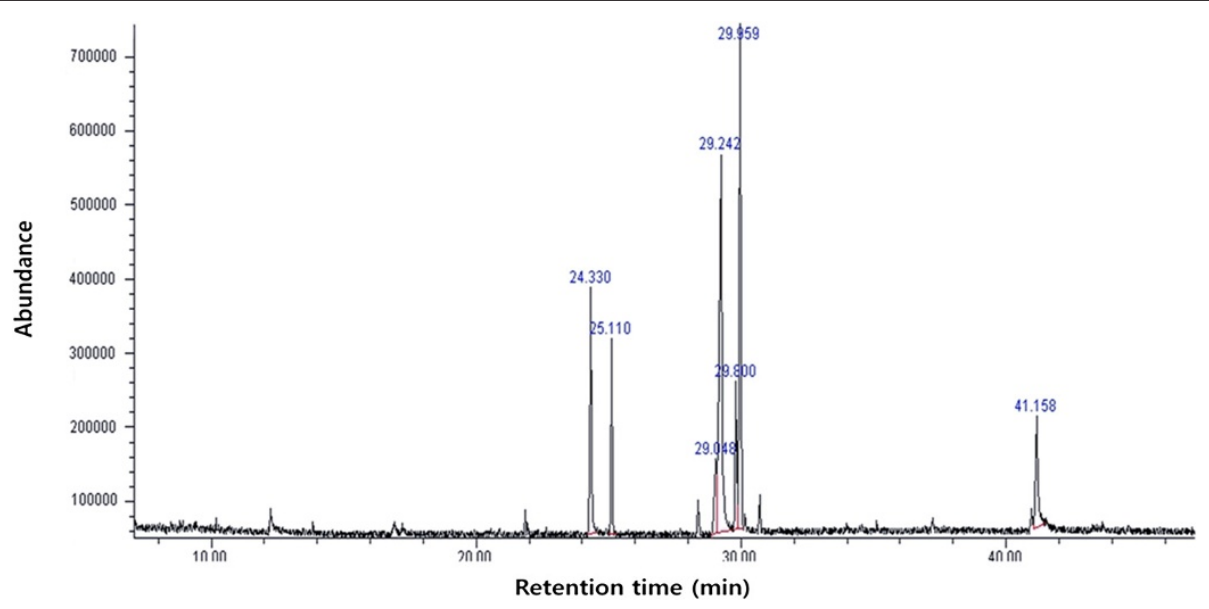

Figure 4 Gas chromatogram of the ethanol extract of Prunella vulgaris var. lilacina. 
(A)

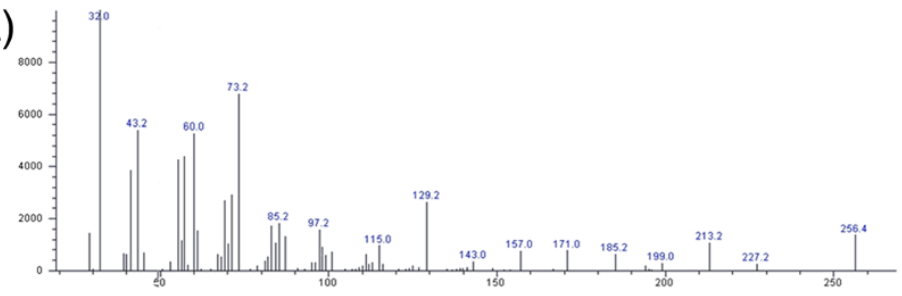

(B)

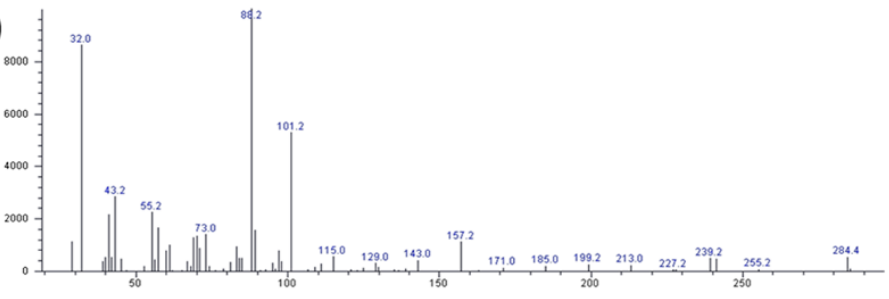

(C)

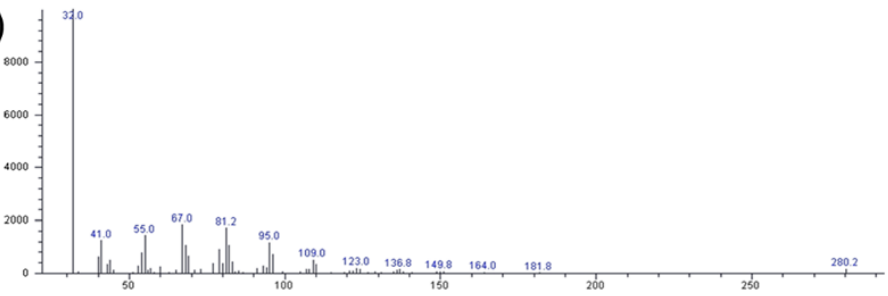

(D)

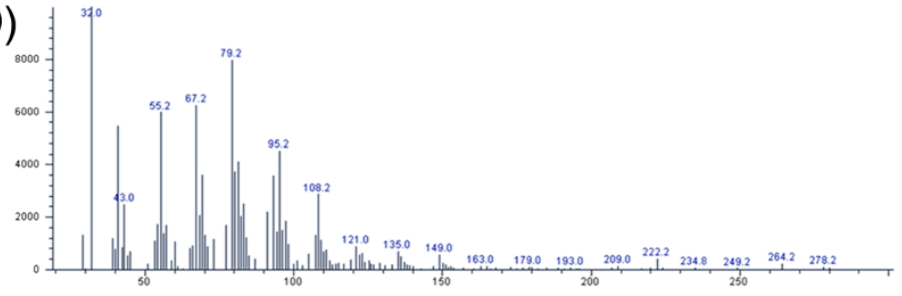

(E)

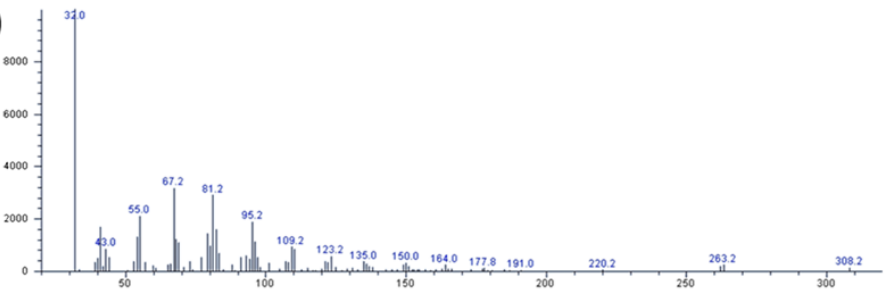

$(\mathrm{F})$

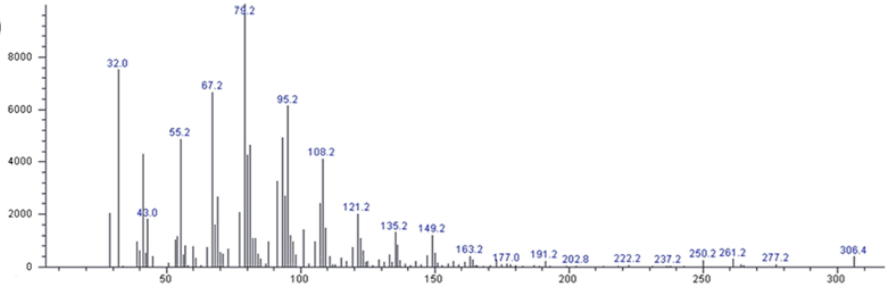

(G)

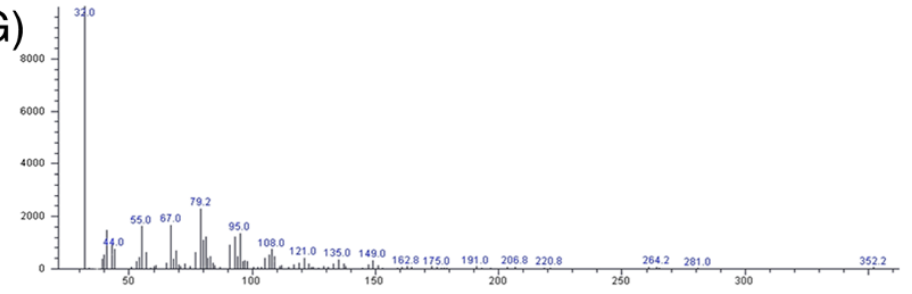

Figure 5 MS Spectrum of the ethanol extract of Prunella vulgaris var. lilacina. The X-axis and Y-axis of the chromatogram show mass/charge $(\mathrm{m} / \mathrm{z}$ ) and abundance, respectively. (A) Hexadecanoic acid; (B) ethyl palmitate; (C) linoleic acid; (D) (z,z,z)-9,12,15-octadecatrienoic acid; (E) ethyl (9E,12E)-9,12-octadecadienoate; (F) (z,z,z)-ethyl ester-9,12,15-octadecatrienoic acid; (G) ethyl linoleolate. 
comparable results for the antioxidant capacity measured in $P$. vulgaris var. lilacina extract and its fractions. The $P$. vulgaris var. lilacina extract and its fractions exhibited strong antioxidant activities against various oxidative systems in vitro. The strong antioxidant activity of a plant extract is correlated with a high content of total phenols $[27,28]$. In our research, we observed that the $P$. vulgaris var. lilacina extract and its fractions that contained higher phenol content exerted stronger radical scavenging effects (Table 3). The correlations between the antioxidant assays, such as DPPH, FRAP, ABTS and SOD activity and phenolic content, were highly positive $(0.759<|\mathrm{r}|<0.993$, $\mathrm{p}<0.01$ ), indicating that the four assays provided comparable values when they were used to estimate the antioxidant capacity of $P$. vulgaris var. lilacina extract. Many studies have shown a good positive linear correlation between antioxidant capacity and the total phenolic content of spices, medicinal herbs, and other dietary plants. Moreover, these results have also suggested that phenolic compounds are responsible for their antioxidant capacity [29-31].

\section{Intracellular ROS scavenging activity}

To investigate the intracellular levels of ROS, the cellpermeable probe DCF-DA was utilized. Non-fluorescent DCF-DA, hydrolyzed to DCFH inside the cells, yields highly fluorescent DCF-DA in the presence of intracellular hydrogen peroxide and related peroxides [32]. We examined whether $P$. vulgaris var. lilacina extract and its fractions inhibited LPS-induced ROS generation. As shown in Figure 1, LPS treatment significantly increased ROS formation in RAW264.7 cells as determined by DCF fluorescence. However, treatment with $P$. vulgaris var. lilacina extract and its fractions blocked LPS-induced ROS generation similar to the results obtained for the antioxidant assays.

\section{Cell cytotoxicity activity}

In order to evaluate the cytotoxic effects of all samples, we performed a preliminary cytotoxicity study with RAW264.7 cells exposed to various sample concentrations $(10,50$, or $100 \mu \mathrm{g} / \mathrm{mL}$ ). The $P$. vulgaris var. lilacina ethanol extract (at 50 and $100 \mu \mathrm{g} / \mathrm{mL}$ ), hexane fraction (at $100 \mu \mathrm{g} / \mathrm{mL}$ ) and chloroform fraction (at 50 and $100 \mu \mathrm{g} / \mathrm{mL}$ ) inhibited cell proliferation, but did not at a concentration of 10 $\mu \mathrm{g} / \mathrm{mL}$ (Figure 2). Conversely, the groups treated with $10 \mu \mathrm{g} / \mathrm{mL}$ of ethanol extract or butanol fraction or treated with 10,50 and $100 \mu \mathrm{g} / \mathrm{mL}$ of the water fraction showed a proliferative effect of over $10 \%$. Macrophages are specialized phagocytic cells that attack foreign substances and cancer cells through destruction and ingestion. They also stimulate lymphocytes and other immune cells to respond to pathogens [33]. These results suggest that the ethanol extract, butanol and water fractions of $P$. vulgaris var. lilacina can be used in the treatment of cancer. Based on this result, we determined the appropriate concentration to be $10 \mu \mathrm{g} / \mathrm{mL}$.

Involvement of free radical-mediated cell damage in many different diseases, particularly cancer, led us to evaluate the cytotoxic activities of the ethanol extract and the water fraction of $P$. vulgaris var. lilacina against five human cancer cell lines (liver, HepG2; colon, HT29; lung, A549; stomach, MKN-45; and cervical, HeLa) (Figure 3). The ethanol extract and the water fraction of $P$. vulgaris var. lilacina were most effective on A549 out of all the cancer cell lines; their values were 32.4 and $28.7 \%$ at 10 $\mu \mathrm{g} / \mathrm{mL}$, respectively.

In the present study, the results clearly demonstrate that the P. vulgaris var. lilacina ethanol extract induced significant cytotoxic effects on the various cancer cell lines studies, and these effects were stronger than for the $P$. vulgaris var. lilacina solvent fractions. It may be difficult to determine the contribution of individual components on the overall anticancer effects. In the literature, it has been reported that $P$. vulgaris var. lilacina components such as ursolic acid and rosmarinic acid are responsible for anticancer activities. Woo et al. [34] reported significant apoptogenic activity of $2 \alpha, 3 \alpha$-dihydroxyurs-12-ene-28-oic acid in Jurkat T cells. Lee et al. [35] and Hsu et al. [36] explored the cytotoxic effects of ursolic acid. Psotova et al. [37] found that rosmarinic acid from P. vulgaris var. lilacina exhibited strong anticancer activity. In the present study, we have isolated various presumed active compounds from the ethanol extract of $P$. vulgaris var. lilacina (Figures 4 and 5). The spectrum profile of GC-MS confirmed the presence of 7 major components, which were hexadecanoic acid, ethyl palmitate, lioleic acid, (z,z,z)-9,12,15-octadecatrienoic acid, ethyl (9E, 12E)-9,12-octadecadienoate, (z,z,z)-ethyl ester-9,12,15-octadecatrienoic acid, and ethyl

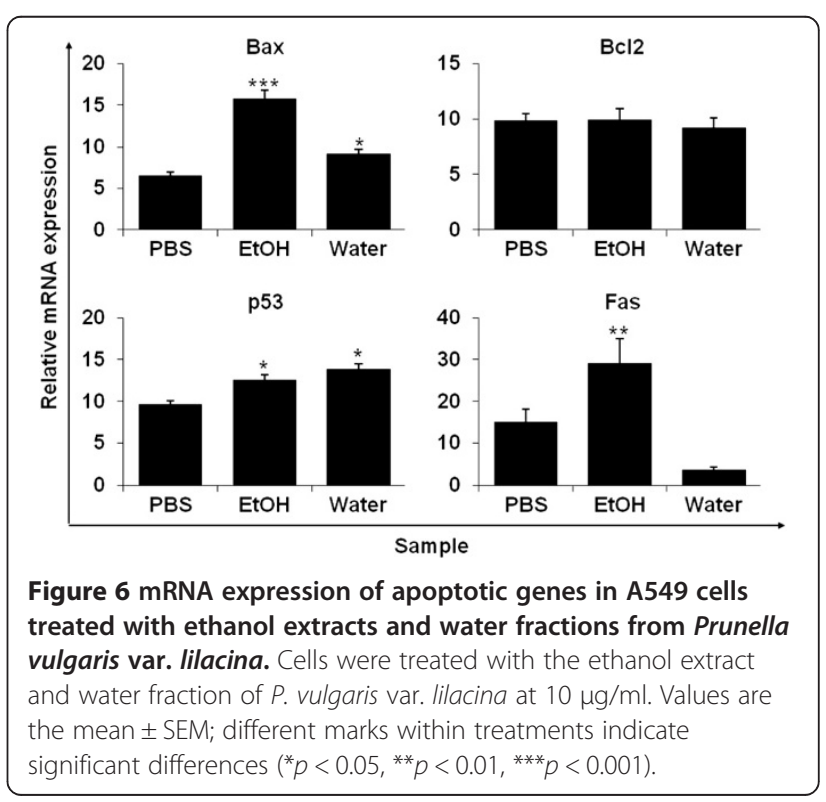


linoleolate. Lai et al. [38] reported significant antitumor effects of fatty acids such as hexadecanoic acid and ethyl palmitate obtained from plant extracts. Taken together, the anticancer activity of ethanol extract may be the result of the synergistic effects of various compounds in $P$. vulgaris var. lilacina, which suggests that $P$. vulgaris var. lilacina can be used as a biological agent in the treatment of cancer.

\section{Real-time RT-PCR analysis}

We assessed whether $P$. vulgaris var. lilacina ethanol extract and the water fraction affected the expression of genes associated with apoptotic cell death, including the tumor suppressor p53,pro-apoptotic Bax, the anti-apoptotic Bcl-2 and Fas genes in A549 cells. p53-mediated apoptosis primarily occurs through the intrinsic apoptotic program [39]. It was reported that p53 induces apoptosis by either increasing transcriptional activity of proapoptotic genes such as Bax or suppressing the activity of the antiapoptotic genes of the Bcl-2 family [40]. Our data show that $P$. vulgaris var. lilacina ethanol extract and the water fraction significantly increased the expression of p53, Bax and Fas compared to the control. However, the expression of Bcl-2 was not decreased compared to that of the control (Figure 6). Therefore, the treatments altered the expression of $\mathrm{Bax} / \mathrm{Bcl}-2$, resulting in a shift in their ratio favoring apoptosis. Several other groups have shown in various cancer cell lines that $P$. vulgaris var. lilacina can lead to cell death by inducing apoptosis through regulation of p53 and Bax/Bcl-2 expression [41]. In our study, the resulting elevation in p53 and Bax protein expression in lung cancer cells is consistent with our earlier proposed involvement of p53 and Bax-related response systems. Taken together, we suggest that $P$. vulgaris var. lilacina ethanol extract and water fraction induce apoptosis through the regulation of p53, Bax, and Fas expression.

\section{Conclusions}

The present study determined that $P$. vulgaris var. lilacina extract and its fractions have strong antioxidant and anticancer activities in vitro. The correlation coefficients between antioxidant capacity and the phenolic content were very strong, and phenolic compounds were a major contributor to the antioxidant capacities of $P$. vulgaris var. lilacina.

In addition, we confirmed the presence of 7 major components of $P$. vulgaris var. lilacina. However, further studies to study the mechanisms of these compounds and find the root of their antioxidative and anticancer activity are underway. On the basis of these results, $P$. vulgaris var. lilacina appears to be a good source of natural antioxidant and anticancer agents and could be of significance in the food industry and for the control of various human and animal diseases.

\section{Additional file}

Additional file 1: Table S1. Extraction yield of Prunella vulgaris var. lilacina.

Abbreviations

ABTS: 2, 2'-Azinibis 3-ethyl benzothiazoline-6-sulfonic acid;

DCF-DA: Dichlorofluorescein diacetate; DMSO: Dimethyl sulfoxide; DPPH: 1, 1-diphenyl-1-picrylhydrazyl; FRAP: Ferric-reducing antioxidant power; GAE: Gallic acid equivalent; LPS: Lipopolysaccharide; ROS: Reactive oxygen species; SOD: Superoxide dismutase; TPTZ: 2, 4, 6-tris(2-pyridyl)-s-triazine.

\section{Competing interests}

The authors declare that they have no competing interests.

\section{Authors' contributions}

$\mathrm{KAH}$ conceived this study and designed the experiments. YJH and EJL performed most of the experiments. All authors including HRK analyzed the data and discussed the results. $\mathrm{KAH}$ supervised the project and wrote the manuscript with the help of $Y J H, E J$ and HRK, and all authors read and approved the final manuscript.

\section{Acknowledgements}

This study was carried out with support from the "Research Program for Agricultural Science \& Technology Development (Project No. PJ008521)", National Academy of Agricultural Science, RDA, Republic of Korea.

\section{Author details}

${ }^{1}$ Department of Agrofood Resources, National Academy of Agricultural Science, RDA, Suwon, Gyeonggi-do 441-853, Republic of Korea. ${ }^{2}$ Department of Biotechnology \& Bioengineering, Sungkyunkwan University, Suwon, Gyeonggi-do 440-746, Republic of Korea.

Received: 12 July 2013 Accepted: 31 October 2013

Published: 9 November 2013

\section{References}

1. Halliwell B, Gutteridge JMC: Free radicals in biology and medicine. J Free Radic Biol Med 1985, 1:331-332.

2. Finkel T, Holbrook NJ: Oxidants, oxidative stress and the biology of ageing. Nature 2000, 408(6809):239-247.

3. Madhavi D, Deshpande S, Salunkhe DK: Food Antioxidants: Technological: Toxicological and Health Perspectives: CRC Press; 1995.

4. Moure A, Cruz JM, Franco D, Dominguez JM, Sineiro J, Dominguez H, José Núñez M, Parajó JC: Natural antioxidants from residual sources. Food Chem 2001, 72(2):145-171.

5. Ito N, Hirose M, Fukushima S, Tsuda H, Shirai T, Tatematsu M: Studies on antioxidants: their carcinogenic and modifying effects on chemical carcinogenesis. Food Chem Toxicol 1986, 24(10):1071-1082.

6. Safer A, Al-Nughamish A: Hepatotoxicity induced by the anti-oxidant food additive, butylated hydroxytoluene $\mathrm{BHT}$, in rats. An electron microscopical study. Histol Histopathol 1999, 14:391-406.

7. Mohsen SM, Ammar AS: Total phenolic contents and antioxidant activity of corn tassel extracts. Food Chem 2009, 112(3):595-598.

8. Chua M-T, Tung Y-T, Chang S-T: Antioxidant activities of ethanolic extracts from the twigs of Cinnamomum osmophloeum. Bioresour Technol 2008, 99(6):1918-1925.

9. Zhu Y-P: Chinese materia medica: chemistry, pharmacology and applications. Boca Raton: CRC Press; 1998.

10. Namba T: The Encyclopedia of Wakan-Yaku: traditional Sino-Japanese medicines, with color pictures. Osaka: Hoikusha; 1994.

11. Lamaison J, Petitjean-Freytet C, Carnat A: Medicinal Lamiaceae with antioxidant properties, a potential source of rosmarinic acid. Pharm Acta Helv 1990, 66(7):185-188.

12. Xu H-X, Lee SH, Lee SF, White RL, Blay J: Isolation and characterization of an anti-HSV polysaccharide from Prunella vulgaris. Antiviral Res 1999, 44(1):43-54.

13. Okuda T, Hatano T, Agata I, Nishibe S: The components of tannic activities in Labiatae plants. I. Rosmarinic acid from Labiatae plants in Japan. Yakugaku Zasshi 1986, 106:1108-1111. 
14. Wang Z: Studies on the chemical constituents from Prunella vulgaris. Acta Pharm Sin 1999, 34:679-681.

15. Jing T, Zhiyan X, Yayan C, Yuying Z, Zhuju W: Structure identification of vulgarsaponin A. Acta Pharmacol Sin 2000, 35:29-31.

16. Lee IK, Lee SY, Kim KR, Choi SU, Hong JK, Lee JH, Park YH, Lee KR: Triterpenoic acids of Prunella vulgaris var. lilacina and their cytotoxic activities in vitro. Archives of Pharm Res 2008, 31(12):1578-1583.

17. Hwang KA, Hwang YJ, Park DS, Kim JH, Om AS: In vitro investigation of antioxidant and anti-apoptotic activities of Korean wild edible vegetable extracts and their correlation with apoptotic gene expression in HepG2 cells. Food Chem 2011, 125(2):483-487.

18. Ryu SY, Oak M-H, Yoon S-K, Cho D-I, Yoo G-S, Kim T-S, Kim K-M: Anti-allergic and anti-inflammatory triterpenes from the herb of Prunella vulgaris. Planta Med 2000, 66(04):358-360.

19. Psotova J, Kolář M, Soušek J, Švagera Z, Vičar J, Ulrichová J: Biological activities of Prunella vulgaris extract. Phytother Res 2003, 17(9):1082-1087

20. Singleton V, Rossi JA: Colorimetry of total phenolics with phosphomolybdic-phosphotungstic acid reagents. American Journal of Enology and Viticulture 1965, 16(3):144-158.

21. Blois MS: Antioxidant determinations by the use of a stable free radical. Nature 1958, 181:1199-1200.

22. Benzie IF: Ferric reducing/antioxidant power assay: direct measure of total antioxidant activity of biological fluids and modified version for simultaneous measurement of total antioxidant power and ascorbic acid concentration. Method Enzymol 1999, 299:15-27.

23. Re R, Pellegrini N, Proteggente A, Pannala A, Yang M, Rice-Evans C: Antioxidant activity applying an improved ABTS radical cation decolorization assay. Free Radic Biol Med 1999, 26(9):1231-1237.

24. Hansen MB, Nielsen SE, Berg K: Re-examination and further development of a precise and rapid dye method for measuring cell growth/cell kill. $J$ Immunol Methods 1989, 119(2):203-210.

25. Wu X, Beecher GR, Holden JM, Haytowitz DB, Gebhardt SE, Prior RL: Concentrations of anthocyanins in common foods in the United States and estimation of normal consumption. J Agric Food Chem 2006, 54(11):4069-4075,

26. Reddy VK, Sreeramulu D, Raghunath M: Antioxidant activity of fresh and dry fruits commonly consumed in India. Food Res Int 2010, 43(1):285-288.

27. Behera BC, Verma N, Sonone A, Makhija U: Optimization of culture conditions for lichen Usnea ghattensis G. Awasthi to increase biomass and antioxidant metabolite production. Food Technol Biotechnol 2009, 47(1):7.

28. Kosanić M, Ranković B, Stanojković T: Antioxidant, antimicrobial, and anticancer activity of 3 Umbilicaria species. J Food Sci 2012, 77(1):T20-T25.

29. Cai Y, Luo Q, Sun M, Corke H: Antioxidant activity and phenolic compounds of 112 traditional Chinese medicinal plants associated with anticancer. Life Sci 2004, 74(17):2157-2184.

30. Liu H, Qiu N, Ding H, Yao R: Polyphenols contents and antioxidant capacity of 68 Chinese herbals suitable for medical or food uses. Food Res Int 2008, 41(4):363-370

31. Shan B, Cai YZ, Sun M, Corke H: Antioxidant capacity of 26 spice extracts and characterization of their phenolic constituents. J Agric Food Chem 2005, 53(20):7749-7759.

32. LeBel CP, Ischiropoulos H, Bondy SC: Evaluation of the probe 2', 7'-dichlorofluorescin as an indicator of reactive oxygen species formation and oxidative stress. Chem Res Toxicol 1992, 5(2):227-231.

33. Wynn TA, Chawla A, Pollard JW: Macrophage biology in development, homeostasis and disease. Nature 2013, 496(7446):445-455.

34. Woo HJ, Jun DY, Lee JY, Woo MH, Yang CH, Kim YH: Apoptogenic activity of 2a, 3a-dihydroxyurs-12-ene-28-oic acid from Prunella vulgaris var. lilacina is mediated via mitochondria-dependent activation of caspase cascade regulated by Bcl-2 in human acute leukemia Jurkat T cells. J Ethnopharmacol 2011, 135(3):626-635.

35. Lee K-H, Lin Y-M, Wu T-S, Zhang D-C, Yamagishi T, Hayashi T, Hall IH, Chang $\mathrm{J}-\mathrm{J}, \mathrm{Wu} \mathrm{R}-\mathrm{Y}$, Yang T-H: The cytotoxic principles of Prunella vulgaris, Psychotria serpens, and Hyptis capitata: ursolic acid and related derivatives1. Planta Med 1988, 54(04):308-311.

36. Hsu Y-L, Kuo P-L, Lin C-C: Proliferative inhibition, cell-cycle dysregulation, and induction of apoptosis by ursolic acid in human non-small cell lung cancer A549 cells. Life Sci 2004, 75(19):2303-2316.

37. Psotova J, Svobodova A, Kolarova H, Walterova D: Photoprotective properties of Prunella vulgaris and rosmarinic acid on human keratinocytes. J Photochem Photobiol B Biol 2006, 84(3):167-174.
38. Lai CS, Mas RH, Nair NK, Maji MI, Mansor SM, Navaratnam V: Typhonium flagelliforme inhibits cancer cell growth in vitro and induces apoptosis: an evaluation by the bioactivity guided approach. J Ethnopharmacol 2008, 118:14-20.

39. Soengas MS, Alarcon R, Yoshida H, Hakem R, Mak T, Lowe S: Apaf-1 and caspase-9 in p53-dependent apoptosis and tumor inhibition. Science 1999, 284(5411):156-159.

40. Miyake H, Hanada N, Nakamura H, Kagawa S, Fujiwara T, Hara I, Eto H, Gohji K, Arakawa S, Kamidono S: Overexpression of $\mathrm{Bcl}-2$ in bladder cancer cells inhibits apoptosis induced by cisplatin and adenoviral-mediated p53 gene transfer. Oncogene 1998, 16(7):933-943.

41. Feng L, Au-yeung W, Xu YH, Wang SS, Zhu Q, Xiang P: Oleanolic acid from Prunella Vulgaris L. Induces SPC-A-1 cell line apoptosis via regulation of Bax, Bad and Bcl-2 Expression. Asian Pac J Cancer Prev 2011, 12:403-408.

doi:10.1186/1472-6882-13-310

Cite this article as: Hwang et al.: In vitro antioxidant and anticancer effects of solvent fractions from prunella vulgaris var. lilacina. BMC Complementary and Alternative Medicine 2013 13:310.

\section{Submit your next manuscript to BioMed Central and take full advantage of:}

- Convenient online submission

- Thorough peer review

- No space constraints or color figure charges

- Immediate publication on acceptance

- Inclusion in PubMed, CAS, Scopus and Google Scholar

- Research which is freely available for redistribution
Ciomed Central 